\title{
Pemeriksaan Tungau Debu Rumah (Tdr) Pada Debu Kasur Di Pondok Pesantren Attamadun Kota Batam
}

\author{
Rosi Esa Gustina1*, Putri Anni ${ }^{2}$ \\ ${ }^{12}$ Prodi DIII Analis Kesehatan, Akademi Analis Kesehatan Putra Jaya Batam, Indonesia, \\ 29424
}

E-mail:*rosi_esa_gustina@yahoo.com

DOI : https://doi.org/10.37339/jurpikat.v2i3.725

Info Artikel:

Diterima :

2021-10-05

Diperbaiki :

2021-10-06

Disetujui :

2021-10-11

Kata Kunci: Kepadatan,TDR, Debu Kasur
Abstrak: Tungau Debu Rumah (TDR) merupakan salah satu substansi alergen yang dapat memicu reaksi alergi. Keberadaan TDR dikaitkan dengan manifestasi alergi pada saluran pernafasan dan kulit. Pengabdian ini bertujuan mengetahui hasil pemeriksaan TDR pada debu kasur di Pondok Pesantren Attamadun Kota Batam. Metode Pemeriksaan yang digunakan dengan teknik flotasi. Pemeriksaan TDR dilakukan pada 20 sampel debu kasur santri di Pondok Pesantren Attamadun Kota Batam. Hasil pemeriksaan diperoleh, 15 (75\%) sampel positif TDR dari 20 sampel yang di periksa. Spesies TDR yang ditemukan, yaitu Dermatophagoides pteronyssinus sebanyak 18 (46\%) ekor TDR, Dermatophagoides sp sebanyak 15 (39\%) ekor TDR dan Dermatophagoides farinae sebanyak 6 (15\%) ekor TDR. Hasil perhitungan kepadatan TDR diperoleh rerata kepadatan TDR adalah 22,85 tungau/gram debu, dengan kategori rendah. Berdasarkan hasil yang diperoleh diharapkan kepada pengurus Pesantren Attamadun agar mengedukasi kepada santri untuk merawat kasur dan menjaga kebersihan kamar agar tidak menjadi tempat perkembangbiakan TDR, melakukan pemeriksaan kesehatan rutin santri.

Abstract: House Dust Mite (TDR) is one of the allergen substances that can trigger allergic reactions. The presence of TDR is associated with allergic manifestations in the respiratory tract and skin. This service aims to find out the results of the TDR examination on mattress dust at the Attamadun Islamic Boarding School, Batam City. The examination method used is the flotation technique. The TDR examination was carried out on 20 samples of dust from the mattresses of students at the Attamadun Islamic 
Keywords: Density,TDR, Mattress Dust
Boarding School, Batam City. The results of the examination were obtained, 15 (75\%) TDR positive samples of the 20 samples examined. The TDR species found were 18 (46\%) TDRs, Dermatophagoides sp. 15 (39\%) TDRs and $6(15 \%)$ TDRs Dermatophagoides farinae. The results of the calculation of TDR density obtained that the average TDR density was 22.85 mites/gram dust, with a low category. Based on the results obtained, it is expected that the administrators of the Attamadun Islamic Boarding School should educate the students to take care of the mattress and maintain the cleanliness of the room so that it does not become a breeding ground for TDR, conduct routine health checks for students.

\section{Pendahuluan}

Tungau Debu Rumah (TDR) merupakan salah satu substansi alergen yang memicu reaksi alergi. Keberadaan TDR dikaitkan dengan manifestasi alergi pada saluran pernafasan dan kulit. Bagian tubuh TDR yang bisa menjadi alergen, yaitu kutikula, organ seksual, saluran pencernaan serta feses dan TDR yang sudah mati. Feses TDR memiliki komponen antigen yang dapat masuk ke dalam tubuh manusia melalui proses inhalasi (Sungkar S, 2009). Terdapat sekitar 16 genus dan 46 spesies dari TDR yang dikaitkan sebagai pencetus reaksi alergi, diantaranya Dermatopagoides pteronyssinus, Dermatopagoides farinae, Dermatopagoides microseras dan Euroglyphus maynei (Pongalunggu dkk., 2015). Peneltian yang dilakukan oleh Terreehorst (2002) terhadap 325 pasien atopi menunjukkan bahwa 92\% pasien asma dan $85 \%$ pasien dermatitis atopi memiliki prevalensi tinggi terhadap gejala rhinitis alergi yang berhubungan dengan TDR, adanya gejala hidung pada penderita asma bronkial atau dermatitis atopik yang dialami pasien dikaitkan dengan kepekaan yang tinggi terhadap TDR.

Indonesia merupakan negara kepulauan yang dikelilingi oleh laut. Hal ini menyebabkan Indonesia termasuk negara tropis yang merupakan tempat potensial perkembang biakan TDR (J.S.B Tuda $d k k$., 2013). Kota Batam memiliki luas wilayah daratan seluas $715 \mathrm{~km}^{2}$ dengan luas wilayah keseluruhan mencapai $1.575 \mathrm{~km}^{2}$. Kota batam memiliki suhu rata-rata 26-34oC, Kota ini memiliki dataran yang berbukit dan berlembah. Kondisi tersebut memungkinkan Kota Batam berpotensi menjadi tempat perkembangbiakan spesies TDR. Dimana suhu optimal bagi perkembangan popolasi TDR adalah 25-300C, dengan kelembaban relatif 70-80\% dan kelembaban kritis 60$65 \%$. Populasi dan kepadatan tungau tertinggi terjadi pada musim yang lembab dan kepadatan tungau terendah terjadi di daerah dataran tinggi (Kawulur $d k k ., 2013$ ). 
Menurut data Dinas Kesehatan Kota Batam, terdapat 115 kasus rhinitis alergi pada tahun 2019, dengan jumlah kasus terbanyak ditemukan pada Kecamatan Sekupang Kota Batam, sebanyak 115 kasus (Dinas Kesehatan Kota Batam, 2020).

Pesantren adalah sebuah Badan Pendidikan yang para siswanya diharuskan tinggal bersama. Di kota Batam terdapat Pondok Pesantren Attamadun, dengan total jumlah 80 orang santri. Pondok Pesantren Attamadun memiliki 4 ruang kamar tidur, dengan jumlah kasur sebanyak 30-40 kasur, masing-masing kamar di tempati oleh 1520 orang santri. Kondisi kamar dapat digambarkan pengap, tanpa Air Conditioner $(A C)$, berdebu, panas, terdapat tumpukan barang-barang yang dimiliki oleh para santri. Sebagian besar kegiatan biasanya dilakukan oleh santri di dalam ruangan tsb. Secara keseluruhan kamar yang ditempati santri di pondok pesantren Attamadun terlihat pengab, lembab dan dengan kebersihan yang kurang terjaga. Tungau Debu Rumah (TDR) berkembang secara optimal pada kondisi dengan kebersihan yang kurang, berdebu serta kelembaban yang cukup tinggi (Sungkar S, 2009).

Berdasarkan penelitian yang dilakukan oleh Yolazenia (2019) dengan lokasi penelitian pada 4 panti asuhan di kota Pekanbaru, ditemukan pada keempat panti asuhan didapatkan TDR, dengan kepadatan TDR rata-rata 9,11/gram debu. Sebagian besar anak-anak penghuni panti asuhan pernah mengalami gejala rhinitis alergi (81,2\%). Hal ini menggambarkan kondisi lingkungan yang kurang terjaga kebersihannya sangat berpotensi menjadi tempat perkemabangbiakan bagi TDR.

Faktor lain yang menyebabkan tingginya keberadaan TDR di kamar tidur adalah karena kamar tidur banyak mengandung bahan serat-serat sehingga lebih mudah menampung debu seperti kasur, selimut, sprai, boneka, sofa dan sarung bantal. Kasur dapat menjadi tempat perkembang biakan yang cocok bagi TDR. Keringat dan serpihan kulit manusia yang tertinggal pada kasur merupakan makanan bagi TDR. Disamping itu, lama penggunaan kasur juga akan berpengaruh terhadap perkembang biakan TDR. Pada kasur kapuk dengan penggunaan jangka yang lama akan menjadikan kasur kapuk menjadi keras, hal ini menunjukkan cadangan makanan TDR yang makin berlimpah (Widiastuti, 1996). Penelitian yang dilakukan oleh Faiza (2006), memperlihatkan hubungan positif yang sangat kuat antara lama penggunaan kasur kapuk dengan jumlah populasi TDR, yang berarti semakin lama penggunaan kasur, maka jumlah populasi TDR cenderung meningkat. Berdasarkan hal tersebut maka dilakukanlah pemeriksaan Kepadatan Tungau Debu Rumah (TDR) pada Debu Kasur di Pondok Pesantren Attamadun Kota Batam. 


\section{Metode}

Metode yang digunakan dalam Kegiatan Pengabdian Masyarakat adalah dalam bentuk pemeriksaan TDR, menggunakan teknik flotasi. Sampel yang digunakan sejumlah 20 sampel debu kasur santri di Pondok Pesantren Attamadun Kota Batam. Berikut adalah prosedur pemeriksaan TDR pada Debu Kasur di Pondok Pesantren Attamadun Kota Batam.

Pengambilan Sampel

Sampel pemeriksaan adalah debu kasur yang dikumpulkan dari kasur di Pondok Pesantren Attamadun Kota Batam. Pengambilan sampel menggunakan vacum cleaner maximus 400 watt. Sampel debu kemudaian disimpan dalam plastik klip. Plastik klip yang telah berisi debu kamar diberi label sesuai dengan sumber debu. Setelah itu debu yang telah terkumpul dibawa ke Laboratorium Parasitologi Akademi Analis Kesehatan Putra Jaya Batam untuk dilakukan pemeriksaan.

Pemeriksaan Sampel

Pemeriksaan TDR dilakukan menggunakan Metode Flotasi (Vooehorst, 1965), dengan tahapan, yaitu debu yang telah terkumpul masing-masing tempat pengambilan disaring dengan menggunakan saringan. Kemudian diambil debu sebanyak 0,1 gram, dimasukkan ke dalam tabung reaksi/tabung sentrifus. Tambahkan $3 \mathrm{ml}$ Alkohol 80\%, dikocok kemudian dibiarkan selama 24 jam. Keesokan harinya supernatan dibuang, lalu ditambahkan ke dalam tabung tersebut larutan $\mathrm{NaCl}$ jenuh sampai penuh dan tampak permukaan larutan yang cembung. Kemudian ditutup dengan kaca penutup dan dibiarkan selama 30 menit. Setelah itu kaca penutup diambil dan diletakkan di atas kaca objek selanjutnya diperiksa di bawah mikroskop cahaya dengan perbesaran 100x.

Identifikasi Spesies dan Pemeriksaan Kepadatan Tungau Debu Rumah

Debu yang telah terkumpul disaring dengan menggunakan saringan. Kemudian debu hasil saringan dimasukkan dalam beaker glass kemudian dimasukkan ke tabung reaksi. Ditambahkan alkohol $80 \%$ sebanyak $3 \mathrm{ml}$ dan diamkan selama 24 jam setelah itu dihomogenkan. Kemudian subnatan dibuang dan tambahkan $\mathrm{NaCl}$ jenuh hingga cembung dan ditutup dengan cover glass dan didiamkan selama 30 menit kemudia cover glass diletakkan di objek glass lalu amati dibawah mikroskop perbesaran 40x. 
Metode untuk mendeteksi kepadatan tungau adalah dengan cara meletakkan sejumlah debu pada permukaan dan memeriksanya dengan perbesaran 40x. Tungau kemudian diidentifikasi spesies dan jenisnya, lalu dicatat. Kepadatan TDR dapat dihitung menggunakan rumus Menurut Walangare, Tuda dan Runtuwene (2013) kepadatan TDR dapat dihitung menggunakan rumus sebagai berikut:

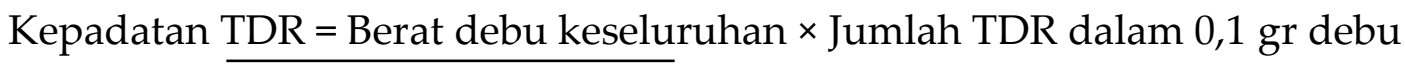
0,1

Alur prosedur pemeriksaan TDR pada debu kasur di Pondok Pesantren Attamadun Kota Batam, disajikan dalam Gambar 1, berikut. 


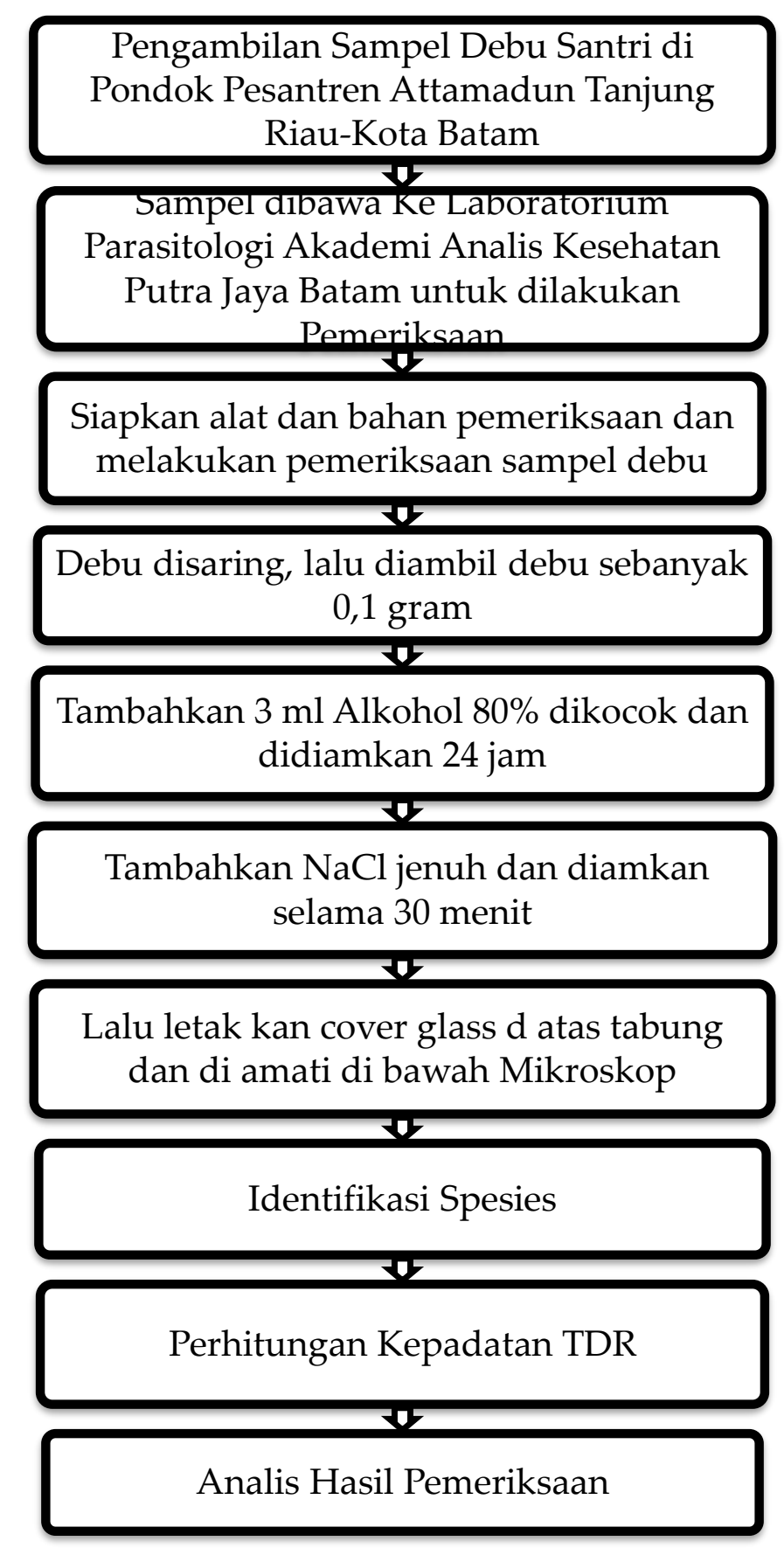

Gambar 1. Alur Pemeriksaan TDR pada Debu Kasur di Pondok Pesantren Attamadun Kota Batam

\section{Hasil dan Pembahasan}

Hasil

Pemeriksaan tungau debu rumah (TDR) pada debu kasur di Pondok Pesantren Attamadun Kota Batam dilakukan terhadap 20 sampel debu kasur santri di Pondok Pesantren Attamadun Kota Batam. Pemeriksaan sampel debu dilakukan di Laboratorium Parasitologi Akademi analis Kesehatan Putra Jaya Batam. Kegiatan 
Pemeriksaan TDR pada debu kasur di Pondok Pesantren Attamadun meliputi beberapa tahapan, yaitu penentuan debu kasur positif atau negatif TDR, kemudian melakukan identifikasi spesies TDR dan dilanjutkan dengan perhitungan kepadatan TDR. Adapun hasil penelitian yang diperoleh dapat dilihat pada tabel berikut:

Tabel 1. Hasil Pemeriksaan TDR pada Debu Kasur di Pondok Pesantren Attamadun Kota Batam

\begin{tabular}{lll}
\hline Hasil & Jumlah & \% \\
\hline Kasur $(-)$ & 5 & 25 \\
Kasur $(+)$ & 15 & 75 \\
\hline Total & 20 & 100 \\
\hline
\end{tabular}

Berdasarkan Tabel 1, ditemukan sebanyak 15 (75\%) sampel debu kasur positif TDR dan sebanyak 5 (25\%) sampel debu kasur negatif TDR.

Tabel 2. Jenis TDR yang ditemukan pada debu kasur di Pondok Pesantren Attamadun Kota Batam

\begin{tabular}{lll}
\hline Jenis TDR (Spesies praduga) & $\begin{array}{l}\text { Jumlah } \\
\text { TDR }\end{array}$ & $\begin{array}{l}\text { Persentase } \\
(\mathbf{\%})\end{array}$ \\
\hline Dermatophagoides sp & 15 & 39 \\
Dermatophagoides pterennissinus & 18 & 46 \\
Dermatophagoides farinae & 6 & 15 \\
\hline Total & 39 & 100 \\
\hline
\end{tabular}

Berdasarkan hasil identifikasi jenis TDR yang ditemukan pada Tabel 2 terlihat spesies Dermatophagodes pteronyssinus merupakan jenis TDR yang paling banyak ditemukan, yaitu 18 ekor TDR (46\%), spesies Dermatophagoides sp ditemukan sebanyak 15 ekor TDR (39\%) dan jenis TDR yang paling sedikit ditemukan adalah spesies Dermatophagoides farinae sebanyak 6 ekor TDR (15\%).

Tabel 3 Rerata Kepadatan TDR pada Debu Kasur di Pondok Pesantren Attamadun Kota Batam

\begin{tabular}{ll}
\hline Jumlah Sampel & Rerata Kepadatan TDR \\
\hline 20 Sampel Debu & 22,85 tungau/gram debu \\
\hline
\end{tabular}


Berdasarkan Tabel 3, diketahui bahwa rerata kepadatan TDR pada 20 sampel debu kasur santri di Pondok Pesantren Attamadun Kota Batam adalah 22,85 tungau/gram debu, tergolong kedalam kategori rendah. Menurut WHO, Kepadatan TDR sebanyak 100-500 tungau/gram debu dikategorikan rendah.

\section{Pembahasan}

Pemeriksaan kepadatan tungau debu rumah (TDR) pada debu kasur di Pondok Pesantren Attamadun Tanjung Riau-Kota Batam dilakukan melalui beberapa tahapan, diantaranya dilakukan pengukuran suhu dan kelembapan pada kamar santri di Pondok Pesantren Attamadun Kota Batam, kemudian dilanjutkan dengan penentuan sampel dan pengambilan sesuai dengan kriteria eklusi dan inklusi.

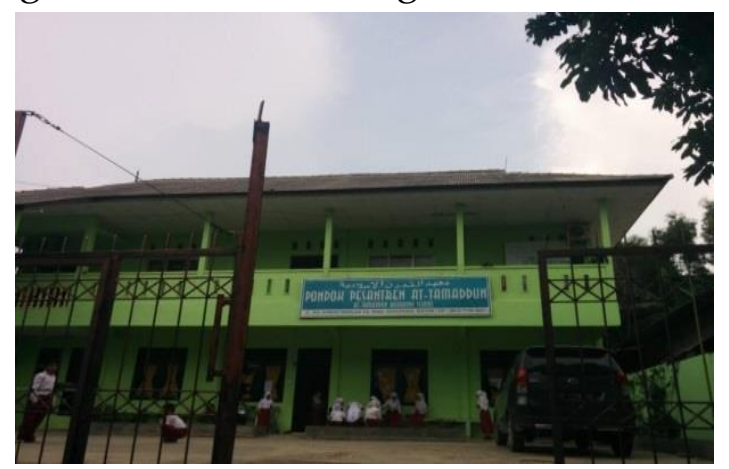

Gambar 2. Pondok Pesantren Attamadun Tanjung Riau-Kota Batam

Pengambilan sampel dilakukan menggunakan vakum cleaner Maximus 400 watt, penyedotan debu dilakukan pada bagian tepi kasur selama 2 menit dengan luas area kasur $1 \mathrm{~m} 2$ untuk masing-masing kasur pada ruang tidur santri di Pondok Pesantren Attamadun Kota Batam. Total debu kasur yang diperoleh dari 20 sampel kasur adalah 22,37 gram debu. Sampel yang telah diperoleh selanjutnya dibawa ke Laboratorium Parasitologi Akademi Analis Kesehatan Putra Jaya Batam untuk dilakukan pemeriksaan.

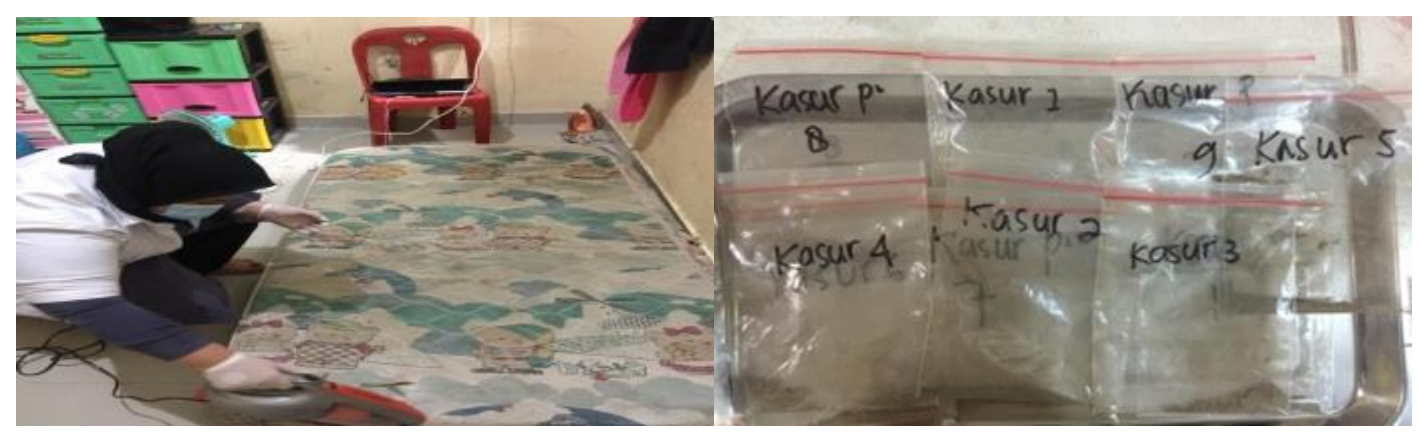

Gambar 3. Proses Pengambilan sampel 
Berdasarkan hasil pemeriksaan terhadap 20 sampel debu kasur dari 8 kamar santri di Pondok Pesantren Attamadun Kota Batam diperoleh hasil sebanyak 15 (75\%) sampel positif TDR dan sebanyak 5 (25\%) sampel negatif TDR (Tabel 1). Besarnya jumlah sampel positif TDR yang ditemukan diduga terkait dengan kondisi yang mendukung bagi perkembangan TDR, dimana pada pemeriksaan suhu dan kelemban kamar, didapatkan rata-rata suhu dan kelembaban pada tiap kamar berkisar antara $26^{\circ} \mathrm{C}$ dengan tingkat kelembaban berkisar 70-80\%, ini merupakan kondisi dimana baik untuk pertumbuhan bagi spesies TDR. Suhu dan kelembaban optimum yang optimal bagi perkembangan populasi TDR, yaitu $25-30^{\circ} \mathrm{C}$ dan kelembaban relatif $70-80 \%$ dengan kelembaban kritis 60-65\% (Pongalunggu $d k k$., 2015).

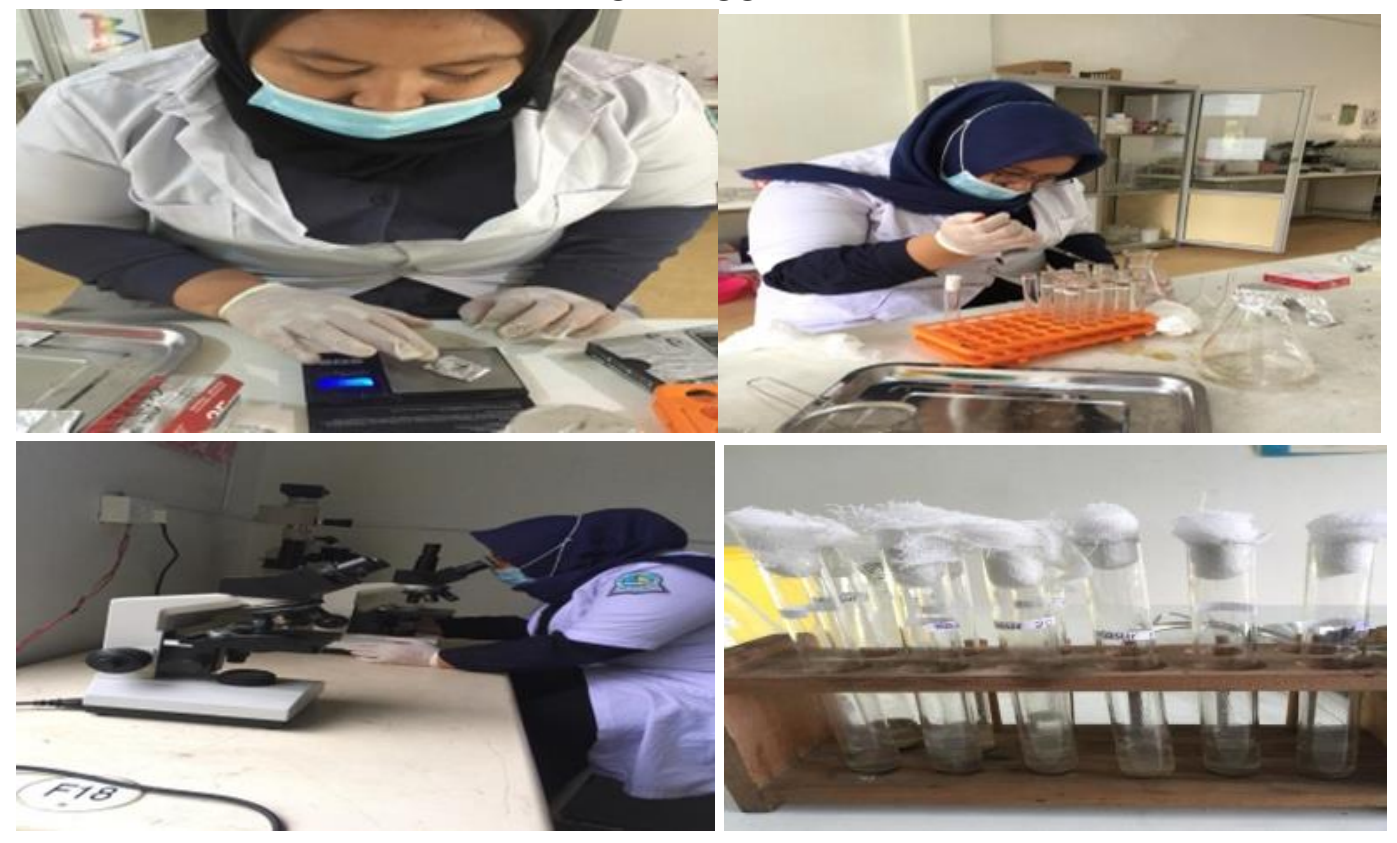

Gambar 4. Proses Penelitian Sample

Faktor risiko lain yang diduga berperan adalah banyaknya penghuni dalam suatu kamar ruangan berkisar 15-20 orang hal ini dapat mempengaruhi penyebaran keberadaan tungau debu rumah (TDR) dan personal hygine yang kurang terjaga dari para santri juga dapat mempengaruhi keberadaan tungau.

Jenis spesies TDR yang ditemukan pada debu kasur di Pondok Pesantren Attamadun Kota Batam, yaitu Dermatophagodes pteronyssinus merupakan jenis TDR yang paling banyak ditemukan, yaitu 18 ekor TDR (46\%), spesies Dermatophagoides sp ditemukan sebanyak 15 ekor TDR (39\%) dan jenis TDR yang paling sedikit ditemukan adalah spesies Dermatophagoides farinae sebanyak 6 ekor TDR (15\%) (Tabel 2). Hasil pemeriksaan ini sesuai dengan beberapa penelitian di berbagai negara dimana spesies TDR yang paling banyak ditemukan adalah spesies Dermatophagoides pteronyssinus. 
Penelitian yang dilakukan oleh Arahmi., dkk (2019) melaporkan bahwa spesies Dermatophagoides pteronyssinus ditemukan paling tinggi di tempat tidur (kasur dan sprei) dan spesies Dermatophagoides farinae ditemukan dengan jumlah yang sangat sedikit. Pada penelitian lain yang dilakukan oleh Galacia (2006) dan Ponggalunggu (2015) juga melaporkan Dermatophagoides pterenyssinus dari famili Pyroglyphidae sebagai spesies tungau yang paling dominan.

Pada perhitungan kepadatan TDR (Tabel 3), diperoleh rerata kepadatan TDR pada 20 sampel debu kasur santri di Pondok Pesantren Attamadun Kota Batam adalah 22,85 tungau/gram debu, jumlah tersebut tergolong kedalam kategori rendah. Menurut Mantu., dkk (2016) kepadatan TDR yang berdampak pada kesehatan adalah 100 tungau/gram yang akan mengakibatkan terjadinya alergi yaitu berupa asma dan dengan 500 lebih tunggau/debu akan mengakibatkan reaksi antibody IgE dan asma. Kepadatan TDR yang berdampak bagi kesehatan berlangsung sejalan dengan kenaikan kepadatan, sehingga semakin tinggi kepadatan maka akan semakin tinggi frekuensi alergi bagi kesehatan.

Jumlah rerata kepadatan TDR yang diperoleh pada debu kasur santri di Pondok Pesantren Attamadun Kota Batam tersebut tergolong lebih rendah apabila dibandingkan dengan penelitian yang telah dilakukan oleh peneliti sebelumnya, antara lain Rahmadatu., $d k k$ (2019) yang melaporkan kepadatan TDR yang ditemukan adalah 28,93 tungau/gram. Kemudian Penelitian yang dilakukan oleh Widiastawan., dkk (2015) yang melaporkan kepadatan TDR yang ditemukan adalah 36,92 tungau/gram.

Walaupun rerata kepadatan TDR pada 20 sampel debu kasur santri di Pondok Pesantren Attamadun Kota Batam tergolong kedalam kategori rendah, namun akan tetap memberikan dampak negatif terutama pada individu dengan Hipersensitivitas Tipe I. Alergen yang terlibat di reaksi hipersensitivitas ini merupakan antigen spesifik yang pada individu normal tidak menunjukan gejala klinis, namun beberapa individu merespon substansi tersebut dengan memproduksi sejumlah besar $\operatorname{IgE}$ dan mengakibatkan terjadinya berbagai manisfestasi klinis alergi. Hampir semua komponen dari TDR merupakan allergen, seperti kutikula, organ seksual, saluran pencernaan serta feses dan TDR yang sudah mati (Sungkar S, 2009). Paparan TDR inilah nantinya akan memicu respons imun pada individu Hipersensitivitas Tipe I atau dikenal juga dengan alergi. Ada beberapa manifestasi alergi yang disebakan oleh TDR, diantaranya pada kulit yang menimbulkan efek berupa alergi atopik dengan lesi terbentuk secara nyata pada penderita Dermatitis atopik. Manifestasi alergi lain yang disebabkan oleh TDR adalah pada saluran pernapasan, yaitu asma bronkia dan 
rhinitis alergi. Komponen dari TDR adalah sebagian besar allergen yang merupakan penginduksi terbentuknya reaksi alergi pada mukosa hidung yang menyebabkan rhinitis alergi pada sistem pernapasan (Mantu., $d k k, 2016)$.

Adapun spesies dominan TDR yang ditemukan pada pemeriksaan adalah Dermatophagoides pterenyssinus. TDR jenis Dermatophagoides pterenyssinus diketahui sebagai sumber utama penyebab alergi pada sistem respirasi (Ponggalunggu., $d k k$ 2015).

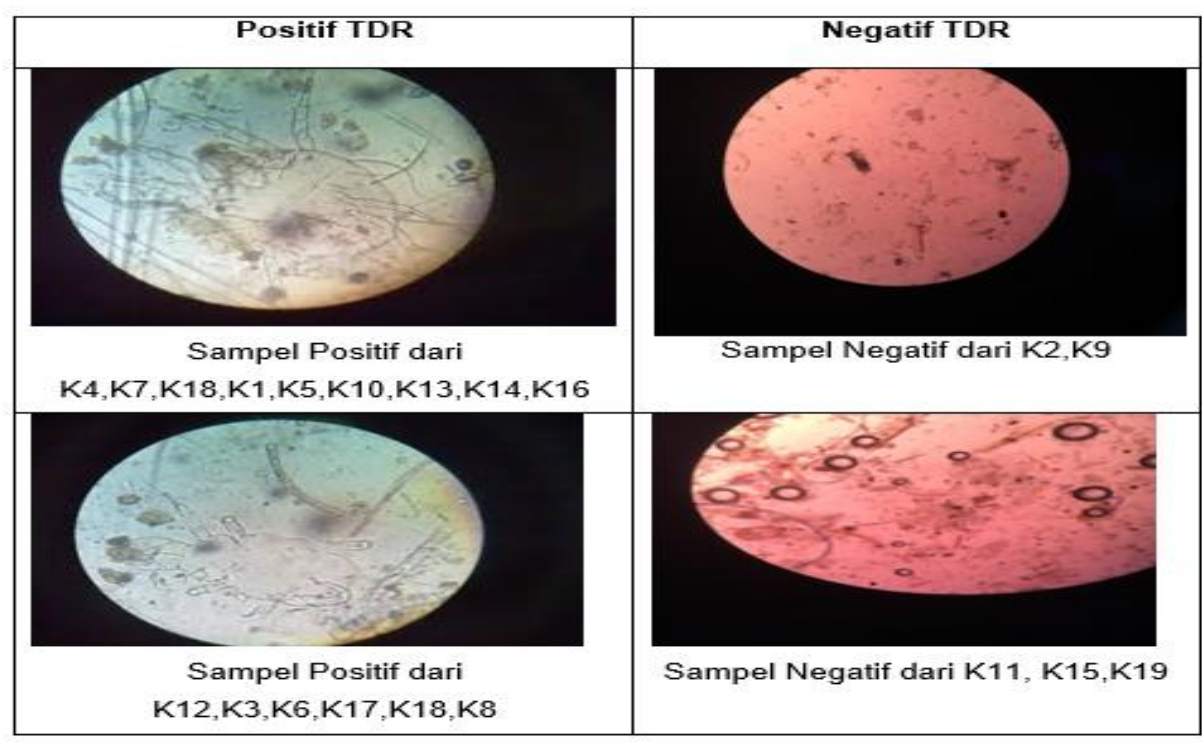

Gambar 5. Hasil Penelitian Debu Positif dan Negatif TDR

Pemeriksaan TDR yang telah dilakukan memiliki beberapa keterbatasan, antara lain Identifikasi spesies tungau hanya didasarkan pada referensi pembanding, yaitu dengan membandingkan ciri-ciri morfologi spesies yang ditemukan dengan referensi (Buku dan Jurnal Penelitian) serta Identifikasi spesies hanya dilakukan pada stadium dewasa.

\section{Kesimpulan}

Jadi dapat disimpulkan bahwa debu pada kasur kasur santri di Pondok Pesantren Attamadun Kota Batam, 75\% positif TDR dengan rerata kepadatan TDR 22,85 tungau/gram debu, dengan kategori rendah, dengan spesies TDR yang paling dominan ditemukan, yaitu Dermatophagoides pteronyssinus sebanyak 18 (46\%) ekor TDR.

Berdasarkan hasil pemeriksaan yang telah dilakukan terdapat beberapa saran untuk kegiantan pengabdian selanjutnya, yaitu agar dapat melakukan identifikasi spesies menggunakan koleksi atau awetan serangga dan didukung dengan kunci determinasi, mengingat TDR merupakan spesies yang sangat kecil dan pembedanya sulit ditemukan. Pengindetifikasian lebih dari satu fase tungau baik fase telur, larva, 
nimpa dan dewasa juga dapat dilakukan untuk menyakinkan proses identifikasi spesies. Pemeriksaan TDR dapat dilakukan pada debu-debu di ruangan-ruangan di Panti Asuhan dan pada lokasi yang berbeda.

\section{Ucapan Terima Kasih}

Ucapan terima kasih kami sampaikan kepada seluruh pengurus Pondok Pesantren Attamadun Kota Batam, yang telah memberikan kesempatan dalam Pelaksanaan kegiatan Pengabdian Masyarakat di Pondok Pesantren Attamadun dan Kepada seluruh Jajaran di Akademi Analis Kesehatan Putra Jaya Batam, yang telah banyak membantu dalam pelaksanaan kegiatan Pengabdian Masyarakat ini.

\section{Referensi}

Faiza.Arif. 2006. Hubungan antara Lama Penggunaan Kasur Kapuk dengan Jumlah Populasi Tungau Debu Rumah di Perumahan PJKA Kelurahan Randusari Semarang (Skripsi). Semarang: Fakultas Kedokteran Universitas Diponegoro.

Hohakay, Y. A., G. J. P. Wahongan \& J. B.B Branadus.2013.Jenis dan Kepadatan Tungau Debu Rumah di Kelurahan Kleak Kecamatan Malalayang Kota Manado. Jurnal e-biomedik. 5(2).

Kawulur, Y. S. B. Tuda \& G. J. P. Wahongan.2013. Jenis dan Kepadatan Tungau Debu Rumah yang di Temukan di Kelurahan Teling Bawah Kecamatan Wenang Kota Manado. Jurnal e-Biomedik 1(3).

Kokali, F. M., A. Sorisi \& V. Pijoh. 2013. Tungau Debu Rumah dikelurahan Ranotana Weru Kecamatan Wanea Kota Manado. Jurnal e-Biomedik. 1(2).

Kristin, S. P., J. S. B. Tunda \& G J.P. Wahongan. 2015. Jenis dan Kepadatan Tungau Debu Rumah dikelurahan Malalayang 1 Kecamatan Malalayang Kota Manado. Jurnal e-Biomedik. 3(3).

Natadisastra, D,. Agoes, R,. 2009. Parasitologi Kedokteran Ditinjau dari Organ Tubuh yang Diserang. Jakarta: Penerbitan Buku Kedokteran EGC

Natalia, D. (2015). Peranan Alergen Tungau Debu Rumah (Der p 1 dan Der p 2) dalam Reaksi Alergi.CDK-227. 42 (4).

Mantu,Wahongan \& J.B.B.Bernadus.2016.Hubungan kepadatan tungau debu rumah dengan derajat rhinitis alergi.Jurnal e-Biomedik.5(2)

Oemiati R, Sihombing M, Qomariah. 2010. Faktor-faktor yang berhubungan dengan Penyakit Asma di Indonesia. Media Litbang Kesehatan 1(XX). 
Ponggalunggu, W. F., V. D. Pijoh \& G. J. P. Wahongan. 2015. Jenis dan Kepadatan Tungau Debu Rumah Pada Beberapa Habitat di Rumah Penderita Penyakit Alergi. Jurnal e-Biomedik. 3(1).

Rahmadatu,D.,E.Sulistyaningsih \& D. Agustina. 2019. Hubungan Kepadatan Dermatophagoides spp. Dengan frekuensi serangan asma pada penderita asma di rs paru jember. Jurnal kedokteran syiahkuala. 19(2) : 64-71

Sembel, Dantje T. 2009. Entomologi Kedoteran. Yogyakarta: C.V Andi.

Sugiyono,Y.(2007).Statistika untuk penelitian . Bandung:Alfabeta

Subahar,R.,Widiastuti \&A.Aulung.2016.Prevalensi dan faktor risiko tungau debu rumah di Pamulang ( Tanggerang ) dan pasar kebo ( Jakarta) . Jurnal Profesi Medika.10(1)

Sutanto, I.,dkk.2013. Buku Ajar Parasitologi Kedokteran. Jakarta: Fakultas Kedoteran Universitas Indonesia.

Sungkar S. 2009. Artropoda Penyebab Alergi dan Reaksi Toksin dalam Buku Ajar Parasitologi Kedokteran. 4 ed. Jakarta: Balai Penerbit FKUI

Tjandra. W. S., J. B. Bernadus \& J. S. B. Tunda. 2013. Survey Prilaku Masyarakat Terhadap Populasi Tungau Debu Rumah di Sekitar Rumah Penduduk Kelurahan Ranotana Weru Kecamatan Wanea. Jurnal e-Biomedik. 1(2).

Terreehorst I, Oosting AJ, Tempels-Pavlica Z., et. al. 2002. Prevalence and Severity of Allergic Rhinitis in House Dust Mite-Allergic Patients with Bronchial Asthma or Atopic Dermatitis. Clin Exp Allergy. 32.

Walangare, K. R., J. S. B. Tua \& J. Runtuwene. 2013. Tungau Debu Rumah di Kelurahan Taas Kecamatan Tikala Kota Manado. Jurnal e-Biomedik. 1(1).

Widiastawan KAW,Wahongan GJB,Bernadus JBB. Jenis dan kepadatan tungau debu rumah di kelurahan Malalayang dua kecamatan Malalayang kota Manado.Jurnal e-Biomedik(eBm).2015;3(3):733-7

Widiastuti. 1996. Pengaruh penjemuran kasur kapuk terhadap populasi tungau debu rumah (TDR) (Tesis). Jakarta:Universitas Indonesia.

Yolazenia, Harianto, Iqbal Teguh Riady. 2019.Gambaran Kepadatan Tungau Debu Rumah Sebagai Pencetus Rinitis Alergi pada Anak Panti Asuhan Pekanbaru.JIK.13 (1). 